\title{
A latinizálás és hiánya a pécsváradi apátság alapítólevelében*
}

1. BALÁZs JÁNos már a múlt század végén született munkáiban hiányosságként rótta fel, hogy nyelvemlékeink vizsgálata csupán a magyar nyelvü szórványokra van tekintettel, és nem terjed ki a magyar nyelvi elemeket tartalmazó latin nyelvü szövegek elemzésére (1980: 290-291, 1989: 101). Néhány évvel később BENKö LoRÁND alkalmazta elsőként ezt a nyelvemlékelemző módszert Anonymus gesztájára (1998, 2003: 70), az utóbbi években pedig már az oklevelek magyar nyelvű szórványait sem a latin szövegtől elkülönítve, hanem annak részeként tárgyalják a nyelvtörténészek (1. pl. HoFFMANN 2004, 2010a: 215-218; SZENTGYÖRGYI 2014: 82-93; SzÖKE 2015: 120-148; KovÁCs 2015: 193-196, 2018: 97-105; HoFFMANN-RÁcz-TóTH 2018: 39-97; a latin szöveget figyelmen kívül hagyó félreértésekhez 1. SZENTGYÖRGYI 2008: 30-32).

Ennek az eljárásnak köszönhetően az oklevelek latin, illetve latinizáló helynevei is nagyobb figyelmet kapnak, hiszen a magyar helyett a latin nyelvü névváltozatok használata tulajdonképpen a beillesztés egyik típusának tartható (vö. HofFmann 2006: 142). Ez a megoldás a szövegszerkesztés szintjén a vulgáris nyelvü helynevekénél jóval egyszerübb helyzetet teremt: a megfelelően deklinált helynevek gördülékenyen válnak a latin szöveg szerves részeivé (vö. Hoffmann 2007: 21, HoffmanN-RÁcz-Tóth 2018: 52). Ugyanez a gondolat jelenik meg BENKŐ LoRÁnDnál is, aki a kérdéshez a magyar helynevek oldaláról közelítve azt mondja, hogy P. mester a vulgáris nyelvü neveknek a beillesztésével sokat küszködött, és ,gyakran csak következetlenségekkel terhes, ad hoc jellegü megoldásokkal operál" (1995: 404). SzEnTGYÖRGYi Rudolf a Tihanyi alapítólevél szövegével a „miért?”, a „mit?” és a „hogyan?” fázisait egymástól elválasztva foglalkozik, és egyéb típusok mellett a (részben) latin vagy latinosított neveket a második fázis, azaz a névszerkezeti és névhasználati kérdések által meghatározható névválasztás eseteként tárgyalja. Kategorizálását azzal indokolja, hogy a választás, az tudniillik, hogy mit kíván a szövegbe illeszteni az oklevélíró, a lexémák (néha szintagmák) szintjén valósul meg, szemben a beillesztés módjának (a hogyannak) a morfológiai természetü eljárásával (SzENTGYöRGYI 2010a: 37-41, 2014: 86-91).

Az oklevél nyelvén szereplö neveknek nincs ugyan közvetlenül forrásértékük a magyar nyelvtörténet szempontjából, az anyanyelvi háttér azonban ezekben az esetekben is felfedhető, ezért vizsgálatuk nem kerülhető meg. A latin nyelvü helynevek használatának a megismerése a magyar nyelvü szórványok feltárását is segítheti (vö. BENKÖ 1996: 224, HofFMANn 2004: 15, HofFMANN-RÁCz-Tóth 2018: 52). GyÖRfFy GyÖrgy szerint az idevágó névhasználat az oklevelekben ,messze a vulgáris nyelven lejegyzett helynevek 1\%-a alatt marad" (1970: 200), a legújabb számítások alapján azonban Magyarország helyeire vonatkozóan ennél magasabb arányban kerülhettek be latin nyelvü helynevek a szórványemlékekbe (HoFFMANN-RÁCZ-TóTH 2018: 52).

\footnotetext{
* A tanulmány az OTKA Posztdoktori Kiválósági Program keretében készült (befogadó intézmény: MTA-DE Magyar Nyelv- és Névtörténeti Kutatócsoport).
} 
A latin és a latinizáló névhasználat alá HofFMANN IstvÁNt követve (2004: 15-38) öt típust sorolok (vö. SzŐKE 2015: 125-148): 1. a hangalak vagy a morfológiai szerkezet módosításával alkotott formákat (pl. Szeged - Zegedinum, KMHsz. 1: 252; Györ - Jeurinum, BÉNYEIРетно̋ 1998: 28), 2. a magyar nevek szóvégének latin szóvégekként való azonosítását (pl. Zsitva - Sitouam, DHA. 1:213), 3. a nevek részfordítását (pl. Nagy-Alpár-maioris Alpar, KMHsz. 1: 195), 4. a magyar nevek lefordításával létrejött latin neveket (pl. Vas[as]-hegy? - Mons Ferreus, KMHsz. 1: 295) és 5. a latin névmegfelelők használatát (pl. Duna - Danubius, KMHsz. 1: 86). A Korai magyar helynévszótár 1. kötetében található több mint 400 ide vonható helynév (föként településnevek, víznevek és hegynevek) közel 2000 latin névadata alapján arra gyanakodhatunk, hogy az öt típus közül a hangalak vagy a morfológiai szerkezet módosítása volt a latinizálás legkedveltebb módja: 2000 adat 44\%-a ezt a típust képviseli (SzÖKE 2008: 271). Ez az arány talán nem független attól, hogy ez az eljárás ,jellemzőbben, de nem kizárólagosan a szemantikailag nem transzparens nevek esetében gyakori” (SzENTGYÖRGYI 2010a: 39). Az említett felmérés alapján a legkevesebb adatot (8\%) a magyar nevek szóvégének latin végződésként való azonosítására idézhetünk (SzőKE 2008: 271).

2. A magyarországi oklevelekben a vulgáris nyelvü helyneveinknek latin nyelven való feltünése nem írható a véletlen számlájára. ${ }^{1}$ Sokkal inkább tarthatjuk tudatos törekvésnek, melynek jól meghatározott szabályai lehettek. Jól mutatja ezt például az, hogy csak bizonyos névcsoportokban (pl. jelentős települések, Európa-szerte ismert vizek vagy nagyobb tájak, illetve országrészek neveinek körében) bukkan fel az idegen nyelvi forma, amely a korabeli presztízsviszonyokkal is összefüggésben van (vö. HofFMANN 2010a: 217; HofFMANN-RÁcZ-Tóth 2018: 49, 65, 75-76).

Igazat kell adnunk HofFMANN Istvánnak abban, hogy az oklevelek latin nyelvü elemeinek használata mögött meghúzódó normák jellegzetességeit (beleértve időbeli elterjedtségüket is) az eddig ilyen szempontból elemzett nyelvemlékeknél gazdagabb forrásanyagra támaszkodva ismerhetjük csak meg teljes egészében (Hoffmann 2007: 53, HoffmanNRÁcz-Tóтн 2018: 75). A Pécsváradi alapítólevél bevonása ebbe a vizsgálati körbe kettős céllal történik: egyrészt tovább gazdagíthatjuk általa az oklevélbeli latin helynevekkel kapcsolatos tudásunkat, másrészt az oklevél e téren alkalmazott megoldásainak a feltárása a Pécsváradi oklevél kronológiai rétegeinek az elhatárolásához is hozzájárulhat némileg.

Általánosan elfogadott vélekedés szerint a Pécsváradi alapítólevél (+1015/+1158 [1220 k.]/1323/1403/PR.; vö. DHA. 1: 67-70) azok közé a Szent István neve alatt fennmaradt oklevelek közé tartozik, amelyek csak egy-egy századokkal későbbi hamisítvány átiratában maradtak fenn (SZENTPÉTERY 1930: 36, 1938: 137-139; SolyMOSI 2006: 194-195), ezért helynévtörténeti és nyelvtörténeti elemzésekor egynél több kronológiai síkkal kell számolnunk. Nyelvtörténeti szempontból például 11. századi (az apátság alapításának a kora, illetve az eredeti oklevél kiállításának a kora), 13. századi (a hamis oklevél keletkezésének az évszázada) és 15. századi (a hamis oklevél átírásának az ideje) ${ }^{2}$ kronológiai rétegekkel.

${ }^{1}$ GYÖRFFY GYÖRGY az 1\%-ra becsült, latin nyelvre fordított helyneveket „lélektanilag indokolt” eseteknek tartja (1970: 200).

${ }^{2}$ Ha szigorúan vennénk a nyelvtörténeti szempontból lehetséges kronológiai rétegek kijelölését, akkor egy negyedik, a 14. századból származó réteget is számításba kellene vennünk, a 15. század eleji átírást ugyanis megelőzte egy 14. századi (1323-as) is. Véleményem szerint azonban egy enynyire differenciált osztályozás nagyobb mértékben nehezítené meg a szórványok értékelését, mint 
Emellett találkozunk az oklevelet interpoláltnak tartó elképzelésekkel is. GYöRFFY GYÖRGY például a falsum, azaz hamis jelzővel illeti az 1015-re datált Pécsváradi oklevelet a kritikai kiadásban (DHA. 1: 63), ${ }^{3}$ de a latin nyelvü kommentárban azt is megengedi, hogy esetleg nem teljes egészében hamis, hanem maxima parte interpolatum, vagyis nagyrészt utólagos betoldásokat tartalmazó interpolált oklevél (DHA. 1: 63, 72).

Függetlenül attól, hogy az oklevél szövege teljes egészében vagy csak bizonyos részleteiben hamis, azaz interpolált, az valószínünek látszik, hogy István király korában is készítettek egy oklevelet, amelyre a hamis oklevél kiállításakor az egyik legfontosabb forrásként tekinthettek. A 11. századi oklevél létezése mellett szólhat például az, hogy a nagyobb monostorok alapítása kétséget kizáróan országos jelentőségü esemény volt (vö. SzovÁK 2001: 42), és a nyugati minta alapján ezeket szokás volt írásban is rögzíteni (vö. SZENTPÉTERY 1930: 34, 1938: 135-136). Előfordulhatott például az, hogy az eredetileg kiállított alapítólevél a későbbiekben nem volt alkalmas jogbiztosító eszköz, mert például István király adományait nem tartalmazta maradéktalanul, és ezért két évszázaddal később, feltehetően az 1220-as években a hiányzó jogi biztosítékok pótlásának szándékával egy hamis okmányt állítottak ki (vö. SzovÁk 2001: 38).

Az apátság alapítása után kutatva könnyebb dolgunk van: István királyról mint a pécsváradi apátság alapítójáról, illetve az alapításról több hiteles forrás is megemlékezik (vö. KISDI 1999: 280, KRISTÓ 1999: 355). Már önmagában a Szent István-i alapítás is indokot nyújtana ahhoz, hogy a fennmaradt oklevélben helynévtörténeti szempontból 11. századi helyneveket keressünk, hiszen a különböző adományok, köztük helynévvel rendelkezö földadományok jogait az oklevél kiállításától függetlenül már a kezdetekben megkapta az apátság, ez biztosította ugyanis a müködésüket. Ha azt is elfogadjuk, hogy valamiféle oklevelet az alapítás korában is kiállíthattak (ehhez 1. még BRESSLAU véleményét; ${ }^{4}$ GYÖRFFY 1969: 203; KRISTÓ 2000: 317, 320; ÉRSZEGI 2000; ThOROCZKAY 2009: 1408), akkor nyelvtörténeti szempontból is joggal gyanítunk 11. századi elemeket az alapítólevélben. ${ }^{5}$ Az oklevél két helyneve, a Sorlogys és a Scedluc kapcsán ezt az elképzelést igyekeztem konkrét példákkal is alátámasztani (SzÖKE 2019a, 2019b).

3. Tanulmányom első felében az alapítólevél olyan magyar nyelvü névelőfordulásait elemzem részletesen, amelyek más oklevelekben szinte kizárólag latinul vagy latinul és magyarul fordulnak elö: azaz valójában a latinizálás itt tapasztalható hiányára világítok rá.

amennyi haszonnal járna, ezért erre a negyedik rétegre nem (minden esetben) leszek tekintettel az oklevél elemzésekor. Legfőbb célom ugyanis az, hogy meghatározzam, mely elemek tartozhatnak a forrásszegény 11. század kronológiai rétegéhez, és melyeknek a lejegyzése mutat a későbbi századokra (vö. SzÖKE 2015: 24).

${ }^{3}$ Az oklevél fentebb idézett datálása is ezt a vélekedést veszi alapul (1. még Gy. 1. kötetének az oklevélből származó adatait).

${ }^{4}$ Idézi SzEnTPÉTERY (1918: 9) és GYöRfFy (1969: 202-203).

${ }^{5}$ Helynévtörténeti szempontból 11. századiak azok a nevek, amelyek István király korához, illetve tágabban értelmezve a 11. századhoz kapcsolhatók. Az oklevél nyelvtörténeti feltárása pedig arra keresi a választ, hogy a későbbi századokból származó oklevél névlejegyzésében megmutatkoznak-e a 11. század helyesírási, illetve hangjelölési jellegzetességei. Ezt a különbségtételt annak ellenére fontosnak és szükségszerünek gondolom, hogy a helynévtörténeti problematikát valójában a nyelvtörténeti analízis részének is tekintem egyúttal. 
A Pécsváradi oklevél írójának ez a szokatlan eljárása - mint látni fogjuk - az alapítólevél kronológiai rétegeinek az elkülönítését is segítheti.

Az oklevelek szövegezésében megmutatkozó egységesülést az írásbeliség hivatali hátteréhez, a kancelláriához, illetve a hiteles helyek intézményéhez szokás kötni: „itt fejlődtek ki azok a szokások és szabályok, melyek az okleveles gyakorlatban bizonyos egyformaságot teremtettek, s melyek az ugyanazon kancelláriából kikerült okleveleket egymáshoz hasonlókká, származásukat pedig felismerhetővé teszik" (SZENTPÉTERY 1930: 5). Nyelvi szempontból a kialakult szokás a magyar nyelvü helynevek latin szövegkörnyezetét, illetve a latin nyelvü elemek megjelenését is befolyásolhatta. A norma megléte nem jelenti ugyanakkor azt, hogy az egyes oklevelek a helynevek rögzítése során egyöntetủen azonos megoldásokat alkalmaztak: a tudatos és ösztönös eljárások még a normák megszilárdulásának az idején is egyidejüleg jelen lehetnek egy-egy szövegben (vö. BENKő 1996: 237, HOFFMANN-RÁcZ-Tóth 2018: 95-96).

Ahhoz, hogy megfelelően értelmezhessük a Pécsváradi oklevél nyelvi megoldásait, utalnunk kell azokra a körülményekre, amelyek az eredeti Pécsváradi oklevél kiállításakor a magyar oklevéladást jellemezték. Nyelvi szempontból a Pécsváradi alapítólevél első kronológiai rétegéhez tartozó elemek a hiteles 11. század eleji oklevélből származó olyan helynevek lehetnek, amelyek változtatás nélkül kerültek át a 13. századi hamis oklevélbe, majd ennek 15. századi átiratába (vö. SzÖKE 2019a, 2019b). Arra az időre vonatkozólag, amikor a Magyar Királyságban a latin nyelvü írásbeliség éppen csak kialakulóban volt, még nem beszélhetünk a későbbi értelemben vett kancelláriáról, így a latin nevek lejegyzését irányító normák sem igen alakulhattak még ki. A magyarországi oklevélírói gyakorlat a királysággal egyidős, létrejöttét a nyugati minta befolyásolta (FEJÉRPATAKY 1885: 10; ECKHART 1910: 714; SZENTPÉTERY 1930: 34-35, 38; Gouth 1936: 6-8; Solymosi 2006: 197-205). Az 1001-1077 közötti időszakot a német császári oklevelek utánzásaként szokás megjelölni a diplomatikában. Szent István okleveleit korábban egyöntetủen Heribert kancellár C jegygyel jelölt, III. Ottó és II. Henrik császárok uralkodása alatt 1002-ig a német császári kancellárián dolgozó nótáriusának a munkái közé volt szokás sorolni (BreSSLAU, ${ }^{6}$ SzEnTPÉTERY 1930: 36-41). GYÖRFFY GYÖRGY volt az, aki a három, egyértelműen István királynak tulajdonítható latin nyelvủ oklevél (a Pannonhalmi, a Pécsi és a Veszprémi oklevél) stílusa, szerkezete, formulái alapján nem egy, hanem három írnokra következtetett (1977: 182, 266-267; 1997: 5-6; DHA. 1: 58; vö. Solymosi 2006: 195). Ez az elképzelés azonban - ismereteim szerint - nem nyert megnyugtató módon igazolást (vö. KRISTó 1999: 60).

E három oklevél mellett - amelyek alapján a latin nyelvủ oklevélírás kezdeteiről szokás képet alkotni - Bresslau a Pécsváradi oklevélről is úgy véli, hogy Heribert C írnok keze alól kerülhetett ki, hiszen a Pannonhalmi oklevéltől eltérő formulái is igazodnak a német kancellária szokásaihoz, ami véleménye szerint egyúttal a 11. századi oklevél létét is igazolja (vö. GYÖRFFY 1969: 202-203, THOROCZKAY 2009: 1391). GYÖRFFY (1969: 203) a Pannonhalmi oklevél alapján készült eredeti Pécsváradi oklevél esetében az írnokot nem Heribert C személyével azonosítja, hanem István király valamely későbbi nótáriusával, de azt is lehetségesnek tartja, hogy csak a király halála után hamisították az oklevelet.

Mindebböl a mostani elemzésünk szempontjából az a legfontosabb, hogy az eredeti 11. századi oklevél - amelynek a lehetséges nyomait kívánjuk feltárni az alapítólevél 15. századi átiratában - egy olyan korban született, amikor a normák még csak kialakulóban

${ }^{6}$ Véleményét idézi SzEnTPÉTERY (1918: 9) és GYÖRFFY (1969: 202-203). 
lehettek. A helynevek szövegkörnyezete szempontjából egy oklevél 11. századi keletkezésére az utalhat például, ha a később szabályosnak mondható eljárásoktól eltérő megoldásokat találunk benne.

A Pécsváradi oklevél latin nyelvü helynévhasználata a Tihanyi alapítólevéllel mutat szorosabb rokonságot. A ránk maradt oklevél a Szent István utáni uralkodók adományaira is kitér (DHA. 1: 72-80), elemzéseim során azonban - ha másra külön nem utalok - csak a Szent Istvánnak tulajdonított első résszel foglalkozom. Ez a rész 41 falut említ meg, és a határleírásokat is beleszámítva mintegy 140 helymegjelölést találunk az oklevélben. Helymegjelölés alatt összefoglalóan a helyneveket, illetve a földrajzi hely (alkalmi) körülírását, nem tulajdonnévi jelölését értem (vö. SzENTGYöRGYi 2009: 63). Ezek között azonban alig van latin nyelvü: még azokban az esetekben is magyar helynevet találunk, ahol a latinizálás később kivétel nélküli (vö. Hoffmann 2010a: 217, 2006: 144). Ez a körülmény a Pécsváradi oklevél későbbi oklevelektől való különbözőségét mutatja.

3.1. Magyarországon az Árpád-korban viszonylag kevés latin exonimával megnevezhető hely volt (HoFFMANN-RÁCZ-TóTH 2018: 53-55), de például az országok és a nagyobb folyók megjelölésének az ,„»irodalmi« szintü formáit az a korabeli norma szerint latinosítva lehetett, volt szokás vagy éppen volt kötelező írni” (BENKŐ 1995: 406). Ide tartozik például az országokon keresztülfolyó Duna elnevezése is, amely a középkori oklevelekben szinte kizárólag latin nyelven, Danubius-ként (esetleg Danobius-ként) szerepel (KMHsz. 1: 86). A magyarországi latinságban használt középkori latin névforma az ókori latin Danuvius-ra vezethető vissza (HoFFMANN-RÁcZ-TóTH 2018: 53).

A Pécsváradi oklevélben a név először Bátatö, majd Kovacs település keleti határpontjaként tünik fel: ,,sexta Batatue nominatur, que ab oriente terminatur Duna”, „nona Chouas nominatur, que ab oriente terminatur Duna" (DHA. 1: 73). A hamis oklevélnek ezt a kivételes magyar nyelvü adatát legutóbb az oklevél készítésének az idejéhez kötötték a magyar helynévadásról szóló monográfia szerzői (HoFFMANN-RÁcz-TóTH 2018: 386).

GYÖRFFY GYÖRGY vélekedése szerint mindkét oklevél (az 1015-ös és az 1158-as) a 13. század 20-as éveiben, II. András korában készült (DHA. 1: 67-68). ${ }^{7}$ A GYÖRFFY munkájában (Gy. 1-4.) a Duna folyóra vonatkozó adatokat szócikkes formában közlő szótárak számos, a hamisítás időszakából - a 13. század 20-as éveiből (tágabban értelmezve a 13. század első feléből) - származó előfordulást tesznek közzé (KMHsz. 1, HA. 1-4.), amelyek között csupán a Pécsváradi oklevél két adata magyar nyelvü. Nem számítva azokat az eseteket, amikor nem magát a folyót, hanem az egyik mellékágát említik jelzős formában: 1210: ,ad Danubium qui vulgo dicitur Agduna” (Gy. 1: 611, HA. 2: 75). Ez a példa más oldalról kiválóan bemutatja a korabeli szokásokat, hiszen még a magyar főtagú összetett nevek közvetlen környezetében is latinul fordul elö a folyó neve (Hoffmann 2004: 16).

A hamis Pécsváradi oklevelet egy évszázaddal később (1323-ban) átírták, majd ezt követi 1403-ban IX. Bonifác pápa átirata, és ennek a bullának a Vatikáni Titkos Levéltárban őrzött registrumkönyvben lévő egykorú másolatából ismerjük az oklevél legrégebbi szövegét (DHA. 1: 65). A fent említett történeti helynévszótárak mellett - amelyek az első átírás korára is csak korlátozottan tartalmaznak adatokat - az átiratok évszázadainak

\footnotetext{
${ }^{7}$ A hamis oklevél keletkezésének az idejét mások is próbálták időhatárok közé szorítani (SzENTPÉTERY 1918: 36, KISS G. 2001: 89), de nyelvi szempontból elhanyagolható különbségek vannak az egyes elképzelések között.
} 
a feltérképezéséhez egyéb forrásokat is bevontam a vizsgálatba: a 14. századhoz az Anjoukori okmánytár 1. (1301-1321) és 2. (1322-1332) kötetét, a 15. századhoz pedig a Hazai okmánytár 8. kötetét. Ezen okmánytárak alapján úgy tünik, hogy a 14-15. században az oklevelet fogalmazó írnokok a Duna neve kapcsán ugyanahhoz a normához igazodtak, mint a 13. században, azaz latinul jegyezték le a folyó nevét. Egy 1430. évi szövegrészletben a Duna latin neve mellett az egyik mellékágát is megnevezik magyarul: „lacunas seu capturas vsonum wlgo Zegÿe dictas Belderduna, alio nomine Nagherduna vocatas in fluuio danub̈̈' (H. 1: 324).

A Duna név a honfoglalás környékétől már használatban lehetett a magyarban (vö. HoFFMANN-RÁcz-Tóтн 2018: 124), ezért - minthogy a hamisítás vagy az átírás(ok) korából való származtatását további előfordulásokkal nem tudjuk alátámasztani - a Pécsváradi oklevél egyedülálló említését sokkal inkább tarthatjuk az eredeti Szent István-kori oklevél nyomát megörző oklevélrésznek. Az oklevél bizonytalan kronológiai státusza erős indokot ad arra, hogy a szokatlan megoldásokat a hamisítás számlájára írjuk, ugyanakkor egy oklevél igen korai volta is lehet az oka a példa nélküli megoldásoknak. Jól ismert, hogy a 11. században a későbbi századokhoz mérten jóval kevesebb oklevelet állítottak ki, és ezek vagy egyáltalán nem, vagy csak átiratban, illetve hamis oklevélbe ágyazva örződtek meg. A 11. század eleji oklevélírásunkat jellemző eljárásokat éppúgy nem ismerjük tehát, mint az oklevél-hamisításnak a helynevek lejegyzését befolyásoló hatását.

Az első eredetiben fennmaradt hiteles oklevelünk, a Tihanyi alapítólevél helyneveinek köréből is több szokatlan jelenséget idézhetünk, ami a későbbi adatok fényében ugyancsak egyedülállónak mutatkozik. Fehérvár esete ráadásul rokonjelenség a Duna itt tárgyalt magyar nyelvü említéseivel is. A Fejér megyei (Székes)fehérvár-nak a Tihanyi alapítólevélből való egyedüli magyar nyelvü említése a sok száz latin nyelvü formával áll szemben csakúgy, mint a Pécsváradi oklevél Duna adata. A magyar változatot ebben az esetben indokolhatja egyrészt az, hogy a név egy kivételes, bonyolult szerkezetben, útirány jelölöjeként szerepel, másrészt azonban az is felvethetö, hogy ,a normatív latin nyelvü helynévhasználat e településre vonatkozóan az oklevél kiadásának idején még nem alakult ki” (HoffMANN 2006: 144, 2010a: 126-139 [különösen 138-139], 217; SzENTGYÖRGYI 2010b: 81, 2014: 86). Korai, azaz 11. század eleji hiteles, eredeti oklevelek hiányában nehéz állást foglalni az oklevél-kiállítás normáit illetően (vö. HofFMANN 2010a: 139, 92. lábjegyzet), az említett szerzők ezért Fehérvár kapcsán valószínübbnek tartják a szövegkörnyezet befolyásoló hatását. A Pécsváradi oklevélben a Duna magyar néven való említését ugyanakkor - amennyiben valóban 11. századi eleji elem a 15. századi változatban fennmaradt oklevélben - ilyen okok nem magyarázhatják, ebben jó eséllyel a latinizálás normáinak kialakulatlanságát láthatjuk. Két Szent István-kori oklevélben feltünik ugyan a folyó neve latin formában (az 1009-es Veszprémi oklevélben: „super Danubium”, DHA. 1: 52; illetve a szintén 1009. évi Pécsi alapítólevélben: „a Danobyo”, DHA. 1: 58), amiből arra következtethetnénk, hogy a 11. század elején ezt a nevet latinul volt szokás leírni, viszont egyik oklevél sem eredetiben, hanem többszörös átiratban maradt ránk (vö. DHA. 1: 49, 54; vö. HoFFMANN 2010b: 77, Póczos 2015: 70), ami miatt 11. századi kronológiai értékelésük nem egyértelmü.

3.2. A határleírást tartalmazó oklevelekben gyakran találunk faneveket, hiszen a fáknak - helyhez kötöttségük és jól megjelölhetőségük okán - a határok kijelölésében kitüntetett szerep jutott. Egyes esetekben csak azt találjuk az oklevélben, hogy a határ egy fánál húzódik (1075/+1124/+1217: „ubi signum Sancti Benedicti est in quadam arbore”, DHA. 
1: 213; 1113: „sunt due arbores super aquam”, DHA. 1: 394), amikor pedig a fajtákat is megnevezik, akkor a fanevek hol latinul, hol magyarul szerepelnek az oklevelekben (HoFFMANN 2004: 42; BÁBA 2012: 69, 2016: 108; HoffMAnN-RÁcz-Tóth 2018: 91). Egy-egy, a Pécsváradi alapítólevél átiratainak korához közel eső keletkezési idejü 14. és 15. századi oklevél határleírásában sorrendben az alábbi formák találhatók: 1327/1327: due arbores tulfa ... arboribus tulfa [...] arbor tulfa [...] arborem kertyani $[\ldots]$ arbore quercus $[. .$. arborem silicis (AO. 2: 295); 1406: ad duas arbores vnam piri et alterius Salicis [...] arbor Quercus [...] vnam magnam arborem succisam vlgo B̈̈k dictam [...] duas arbores wlgo haas appellatas [...] duas arbores quercuum [...] tres arbores pirorum (H. 1: 300-301). Az első oklevélben a négy magyar nyelvü forma (3 tölgyfa, 1 gyertyán) mellett a tölgyfa két alkalommal latinul is előfordul (az arbor silicis magyar megfelelőjéhez 1. SzERÉMI 1883: 141, CsőRE 1972: 22). A 15. századi oklevélben a latin formák vannak nagyobb számban: a 2 magyar nyelvü adattal szemben 5 fanév szerepel az oklevél nyelvén.

A Pécsváradi alapítólevélben 21 határpontot ${ }^{8}$ jelöltek fanévvel: a tölgyfa nyolcszor, a szilfa ötször, a körtvélyfa négyszer, a nyár, a haraszt, ${ }^{9}$ a hársfa és a köris pedig egy-egy alkalommal tünik fel ebben a szerepkörben. A 21 előfordulás között nincs egyetlen latin nyelvü sem (DHA. 1: 73-75). A Tihanyi alapítólevél a fanevek szempontjából is párhuzamba állítható a Pécsváradi alapítólevéllel. Az 1055. évi oklevél mindössze három fát (bokrot) említ, mindegyiket magyar nyelven. Ezek az adatok (monarau buku[r]ea, ad brokina rea, ad kurtuel fa) kivétel nélkül Disznó birtok határleírásában szerepelnek. A 15. században az alapítólevél interpolálása során ezek közül kettőt (ad rubum és ad virgam pirorum) latinul jegyeztek le (DHA. 1: 150, 156; HofFmAnn 2010a: 107). A Tihanyi alapítólevél hiteles és interpolált változata közötti különbség kevés adattal ugyan, de azt mutathatja, hogy a 11. században a faneveket inkább magyar nyelven volt szokás lejegyezni.

A Pécsváradi oklevél magyar nyelvhasználatát a fanevek esetében is indokolhatja talán a 11. század eleji lejegyzésük, illetve ennek a lejegyzésnek a fennmaradása a többszörös átírás ellenére is. Ezt ugyanakkor némileg el is bizonytalanítja az, hogy a hamis alapítólevél keletkezési idejéből több oklevelet is tudunk idézni, ${ }^{10}$ amelyekben kevesebb fanév szerepel ugyan, de mindegyik magyarul: 1256: arbore tulfa [...] arbore gurtanfa $[\ldots]$ arbore jurtanfa $[\ldots]$ arbore tulfa $[\ldots]$ arborem jurtanfa $[\ldots]$ arborem bykfa $[\ldots]$ arbore narfa $[. .$.$] . arboribus$ tulfa (ÁÚO. 7: 427-428), 1278: arborem Tulfa [...] arborem Cherfa [...] arbores Tulfa [...] arborem Tulfa [...] arborem Berecune [...] arborem Haasfa [...] arborem Gurteanfa [...] arbores Bykfa [...] arbores Tulfa [...] arbores Tulfa [...] arbore Bykfa (ÓmOlv. 102-105).

A Pécsváradi oklevél magyar nyelvü lejegyzései kapcsán fontos az elöfordulások státuszát közelebbröl is megvizsgálnunk, a magyar nyelvüséget indokolhatja ugyanis a szórványok tulajdonnévi használata is. A Pécsváradi alapítólevélben - a középkori oklevelezési gyakorlattól eltérően - a magyar nyelvi elemek elött sohasem szerepel sem a latin arbor 'fa' minősítés, sem más latin földrajzi köznév, ${ }^{11}$ de az esetek nagy részében mégis biztosan

${ }^{8}$ A Harumtulfa, Harumkurtuel, Nognar, Chorozt és Keyris szórvány státuszát később részletesen tárgyalom.

${ }^{9}$ A haraszt fanévi státusza kérdéses (vö. BÁBA 2012: 72).

${ }^{10} \mathrm{~A}$ példákat ezúton is köszönöm SzÖCs TiBORnak.

${ }^{11}$ A Pécsváradi alapítólevélre általában is jellemző az, hogy a helynevek előtt is hiányzik a hely fajtáját megmutató (latin) földrajzi köznév. Az appozíciós szerkezetek hiányáról egy másik, a magyar nevek latin szövegkörnyezetével foglalkozó tanulmányomban szólok részletesen (SzÖKE 2020: 114-116). 
faneveknek kell tartanunk az elöfordulásokat. Ilyenek például az oklevél tölgyfa (tulfa, twlfa, Buketulfa [Büke ? tölgyfa]; Surctulfa [Sarok ? tölgyfa]; DHA. 1: 74, 75; KMHsz. 1: 68, 238, 282), a szilfa (Scylfa, Scilfa, Zilfa; DHA. 1: 73-74, KMHsz. 1: 264), a körtvélyfa (Kurtuelfa, Curtuelfa; DHA. 1: 74-75, KMHsz. 1: 165) és a hársfa (Hasfa; DHA. 1: 74, KMHsz. 1: 124) említései.

Az oklevélben van két, fanevet jelzőként tartalmazó adat, amelyeket pedig a földrajzi köznevek hiánya ellenére is összetett helynevekként azonosíthatunk: Kökény kereke (Kuchinkereby [0:-kereky], DHA. 1: 73, Gy. 1: 331) és Köris-aszó (Kewrus ozov, DHA. 1: 75). ${ }^{12}$

A bizonytalanabbul értékelhető esetek közül a Harumtulfa (KMHsz. 1: 124, DHA. 1: 74) és Harumkurtuel (DHA. 1: 74, KMHsz. 1: 123) szórványokat inkább köznévi szerepünek tarthatjuk, amelyek a határleírásokban oly gyakori latin tres arbores kifejezés helyett állhatnak (pl. 1256: tres arbores quercuum, DF. 78961; vö. 1258>336/354: tulfa harumykru, Gy. 2: 541, HA. 2: 62). A Harumtulfa köznévi státusza mellett szól továbbá az is, hogy számos olyan helynevet ismerünk, amelyben a tölgy szerepel (Tölgy-völgy, Gy. 4: 498, 560; HA. 4: 73), de olyat egyet sem, amiben a tölgyfa állna (1. a HA. 1-4. mutatóit). A Harumkurtuel esetében pedig azt fontos kiemelnünk, hogy a fanévi elöfordulások az alapítólevélben körtvélyfa formájúak ugyan (DHA. 1: 74-75), de a körtvély önmagában is jelölheti a fát. Ha jelző áll előtte, akkor például soha nem szerepel mellette a $f a$ (vö. Zelliger 2005: 30, Hoffmann 2010a: 107): 1275: ,ad duas arbores piri Wereskurtuel uocatas" (OklSz. 540).

A nyár fanév egy alkalommal bukkan fel az alapítólevél szövegében: a talán Baranya megyei (vö. DHA. 1: 488) Gorombona határában Nognar alakban (DHA. 1: 74). A magyar nyelvi elem közszói státusza mellett szólhat, hogy - bár a nyár összetett nevek utótagjaként is szerepel: 1295/330/744: vallem Potoknyar (Gy. 3: 152, 180; H. 3: 40) - az oklevelekben tucatjával találunk a Nognar-nak megfeleltethető latin nyelvü szerkezeteket: 1255: magnam populum (ÁÚO. 11: 411), 1329: magnam arborem tremule (H. 2: 61).

Az alapítólevél Haraszt és Köris (Chorozt, Keyris; DHA. 1: 74) magyar nyelvi elemek puszta fanévi helynévként való értelmezését alá tudjuk ugyan támasztani helynévi analógiákkal (Haraszt erdőnévként: 1257: ,in parva silva que dicitur horost,” Gy. 1: 375, KMHsz. 1: 122; Köris erdőnévként: 1252: nemus Keurus, Gy. 1: 400), de ennél konkrétabban sem fanévi szerepüket, sem helynévi státuszukat nem tudjuk meghatározni. Azt azonban fontos megemlítenünk, hogy mindkét határleírásban, amelyben a Haraszt és a Köris előfordul, szerepelnek fanevek határpontként (DHA. 1: 74), illetve az sem lényegtelen, hogy a puszta fanévvel azonos alakú helynevek mind a korai ómagyar kori, mind a mai korpuszban igen kis számban vannak csak jelen (BÁBA 2008: 54).

Összességében tehát mindebből azt látjuk, hogy a fanevet tartalmazó említések egy jelentős része biztosan nem tekinthető helynévnek, vagyis az esetleges tulajdonnévi státusz nem indokolhatja a magyar nyelven való említésüket. A vulgáris nyelvü használat alapján - bár a 13. századból is idéztünk hasonló jelenséget - bizonytalanul ugyan, de talán felvethető, hogy az oklevélnek ez a jellegzetessége a 11. századból való.

3.3. Az oklevelekben tucatjával fordulnak elő földrajzi köznevek, alapvetően háromféle szerepben (SZENTGYÖRGYI 2014: 89; BÁBA 2016: 110, 114): 1. visszautalnak egy korábban

${ }^{12}$ A 21 fanévvel jelölt határpont közé ezeket az előfordulásokat természetesen nem számítottam bele. 
említett helynévre a szóismétlés elkerülése végett (1271: fluvium Chugouaznos [...] eundem fluvium, H. 8: 143; 1291: Nogyfyzpataka [...] in eodem patak, Gy. 2: 501), 2. a helynév elött állva megjelölik a hely fajtáját (1287: vallem Monuroswelge vocata, H. 6: 329), 3. helynévtől függetlenül is előfordulhatnak (+1015//1403/PR: ab austro Aruk, DHA. 1: 73).

A Pécsváradi oklevél határleírásaiban nagy számban találunk földrajzi közneveket (pl. árok: Aruc, Aruk; út: Wt, Vt; nagyút: ${ }^{13}$ Nogwt, Nogut, Nogvt; völgy: Welg; szurdok: Zurduk; tó: Tow; DHA. 1: 73-75). ${ }^{14}$ Ezek egy eset kivételével (villa Neuýg) helynévtől függetlenül szerepelnek az alapítólevélben, és a középkori oklevélírói gyakorlattal ellentétben - amire a magyar és latin nyelvü alakok együttes megjelenése jellemző (vö. pl. SzENTGYÖRGYI 2014: 89) - kettő kivételével (,et hec silva ad pasturam bestiarum” és „villa Neuýg iuxta Kana dimidio miliario in montibus sita”, DHA. 1: 75) magyar nyelven vannak lejegyezve. ${ }^{15}$ A latin és magyar nyelvü (tulajdonnevet pótló) földrajzi köznevek egy oklevélen belüli váltakozása - jelenlegi tudásunk szerint - a Tihanyi alapítólevél óta jellemzi oklevélírásunkat: 1055: ,ad publicam uiam”, ,aruk que ducitur” (SZENTGYÖRGYI 2010c: 25, 27), 1211: „,montem sabulosum”, ,et inde egreditur Ferteu” (KovÁcs 2015: 26), 1293: ,ad vnum fontem”, ,in quoddam mochar” (ÁÚO. 10: 111), 1368: „per unum mezde”, „unam magnam viam" (KárOkl. 1: 307).

A helynévre visszautaló földrajzi köznévi említés hiánya vélhetően nem független attól, hogy a Pécsváradi oklevélben nem a szokásos értelemben vett határleírások szerepelnek, hanem egy-egy birtokot égtájak szerint megadott határpontokkal jelölnek meg: „tricesimasecunda Hirig nominatur, que ab oriente terminatur Sorlogys, ab austro Sedfev, ab occidente Nogvt et Curtuelfa, a septemtrione Hudus" (DHA. 1: 75). ${ }^{16}$ Az idézett birtok leírása egy másik oklevélben is fennmaradt, itt más típusú földrajzi köznévi említéssel is találkozunk (vö. SzÖKE 2019a: 94): +1058//1403: „terminorum Suenye et Sarlos incipit in eadem via et vadit per medium cuiusdam silve versus Kurthimir in vallem Sarlaswodus, deinde ascendit ad magnam viam, per quam itur versus Danubium" (DHA. 1: 178). A második oklevélrészlet jól mutatja azt is, hogy a helynevek mellett található számos közszói értékü helymegjelölést latinul jegyezték le (l. silva, via). A latin és a vulgáris nyelvü használat mögött meghúzódó okokat nehéz meghatározni, de egy-egy uralkodó jelenséget mintegy szabályként is értékelhetünk. Legutóbb SzENTGYöRGYI RUDOLF fogalmazta meg például, hogy „az utak köznévi említése [...] jellemzőbben latinul történik” (2014: 89, vö. Hoffmann 2007: 34-35). A Pécsváradi oklevélben nyugati határpontként említett Nogvt a második szövegrészletben - amennyiben közszói szerkezettel van dolgunk, a szokásokhoz jobban alkalmazkodva - latinul (magnam viam) szerepel.

A helyet jelölő szórványok e szócsoportból kikerülő elemei közszói és tulajdonnévi értékben is szerepelhetnek a határleírásokban, de a „földrajzi köznévi alakú adatok e tekintetben

${ }^{13}$ A nagyút földrajzi köznévi szerepéhez 1. HoffmanN (2007: 35).

${ }^{14}$ Csak a földrajzi köznévvel megegyező alakot mutató megjelölésekre figyeltem, nem voltam tekintettel például a Három-halom (Harumholm, DHA. 1: 74) szórványra.

${ }^{15}$ A GYÖRFFY GYÖRGY által interpoláltnak jelölt részt ezúttal nem elemeztem: „et communem dimittimus cum meis successoribus, tam terris, quam silvis, vineis et piscinis, arundinetis et fenis, excepto nemusculo quodam, quod contiguum est curie Sancti Benedicti, quod sibi soli pertinet" (DHA. 1: 73).

${ }^{16}$ Erre a jelenségre sem a magyar oklevelek, sem a német császári oklevelek (pontosabban Heribert $\mathrm{C}$ oklevelei) körében nem találtam további példát. 
való megítélése még a fanevek nyelvi státusának a vizsgálatánál is jóval több és összetettebb problémát vet fel" (HofFMANN 2004: 52-53, vö. SZENTGYÖRGYi 2014: 89, BÁBA 2016: 115). Van azonban néhány támpont, amely segítheti az adatok besorolását (HoffMANN 2004: 52-57, BÁBA 2016: 115-116). A Pécsváradi oklevél kapcsán ugyanakkor nem annak a megállapítása a legfontosabb feladatunk, hogy például az árok számtalan elöfordulása között van-e tulajdonnévi használatú - ezt egyébként a szórványok szegényes szövegkörnyezete $^{17}$ (ab occidente Welg, a meridie Zurdok, ab oriente terminatur Aruk stb., DHA. 1: 74), illetve a későbbi említések hiánya még az átlagosnál is nehezebbé teszi -, hanem sokkal inkább annak van itt jelentősége, hogy ezeknek az elemeknek szinte csak vulgáris nyelven való szereplése az alapítólevélben nem lehet független a fanevek és a Duna folyó említésétől, és esetleg a 11. századi oklevél megoldásának tarthatjuk.

3.4. Az eddig vizsgált szórványoknak nincs közvetlen nyelvtörténeti forrásértékük, mert például a lejegyzési formájukat nem köthetjük további vizsgálatok nélkül a 11. század elejéhez akkor sem, ha elfogadjuk azt, hogy ezek az elemek - föként a magyar nyelvüségük miatt - ebben az időben kerülhettek bele az oklevél szövegébe. ${ }^{18}$ Vizsgálatuk ugyanakkor azzal - a későbbi elemzéseket is alapjaiban meghatározó - fontos tanulsággal járt, hogy a Duna, a fanevek és a földrajzi köznevek vulgáris nyelven való lejegyzésében esetleg a 11. század eleji oklevélnek a nyoma őrződhetett meg (vö. SzöKE 2019a, 2019b). A 11. század eleje után a fanevek és a földrajzi köznevek nem kizárólag latin nyelven szerepelnek az oklevelekben, a magyar nyelvü adatok között is lehetnek tehát esetleg olyanok, amelyeket később szúrtak be az oklevél szövegébe, hiszen magyar nyelvü említésük a latin mellett ekkor is jellemző volt.

4. A Pécsváradi alapítólevél öt latin névalakja ${ }^{19}$ - a magyar nevek latin szóvégként való azonosításának a kivételével - a latinizálás korábban bemutatott típusainak mindegyikére mutat egy-egy példát.

4.1. A földadományokat leíró részben mindössze két latin alakot találunk. Ezek közül az egyik a Scena abbatis (DHA. 1: 74). A latinos szórendet mutató, részben lefordított birtokos jelzős szerkezet mögött Apát-széna vagy Apát szénája magyar helynevet sejthetünk. A Baranya megyei (vö. KMHsz. 1: 34, DHA. 1: 493) Kövesdi határpontjainak leírásakor tünik fel a név az oklevélben: „vicesimanona Kuestý, que ab oriente terminatur Scena abbatis, a septemtrione Tow, ab oriente Verum et Voduez et Agifei usque ad Nogut" (DHA. 1: 74). Azonosítását nehezíti, hogy Kövesdi település lokalizálása is bizonytalan (a Gy. 1.-ben például nem is szerepel a Baranya megyei települések között). A Pécsváradi alapítólevélben Várkony (a mai Zengővárkony) után szerepel az oklevélben, ezért talán

${ }^{17}$ Ha a földrajzi köznév elött például a quidam (quaedam, quoddam) jelző szerepel, az közszói szerepre utal (HofFMANn 2004: 56, HofFMANN-RÁcz-TótH 2018: 88).

${ }^{18}$ A Pécsváradi oklevél elemzése az oklevélátírási szokásokra vonatkozólag is hasznos információkkal szolgálhat, úgy tünik ugyanis, hogy egy ilyen eljárás során a nevek szövegkörnyezetének megváltoztatása kevésbé volt jellemző, például hogy az átírások korában már igen elterjedt, latin földrajzi köznév + magyar név szerkezetủ említések mintájára a nevek elé illesszenek egy latin fajtajelölőt, vagy a korábban magyarul említett szavakat latinra fordítsák.

${ }^{19}$ Esztergom neve kétszer fordul elö: Strigoniensis és Strigoniensi alakban (DHA. 1: 76). 
azon a környéken kereshető. Feltételezhető, hogy a Scena abbatis megjelölés határpontként állva 'az apát kaszálója, rétje' szemantikai tartalmú lehet. A széna 'rét, kaszáló' jelentése metonimikus jelentésátvitellel alakulhatott ki. Ezt a jelentést nem tüntetik ugyan fel etimológiai szótáraink (TESz., EWUng.), de számos olyan helynévi előfordulást ismerünk, ahol a latin fenetum 'kaszáló' vagy pratum 'rét' (FINÁLY 1884: 1569, BARTAL 1901: 266) jelöli a helyfajtát: 1393: ,fenetum Waralyazena dictum” (OklSz. széna a.). Ez a változás a növénynevek köréből igen gazdagon adatolható (vö. például szölő 'növény' > 'a hely, ahol a növény terem', FKnT. 302). A Scena abbatis névvel azonos szerkezetủ nevet a Tihanyi alapítólevélből is ismerünk: 1055: „petre zenaia” (DHA. 1: 150, HofFMANN 2010a: 148), illetve Erdélyben a szénafü ma is használatos 'kaszáló, rét' jelentésben (FKnT. 295).

Személynevek és személyekre utaló közszók gyakran vesznek részt helynevek létrehozásában. Az ilyen névadás mozgatórugója a személy tulajdonában lévő birtok megnevezésén túl lehet a személy lakóhelyének megjelölésére irányuló szándék, illetve azok a helyek is viselhetik személyek neveit, amelyeken valamilyen jelentös dolog történt velük (HofFMANN 1993: 107-108). A Scena abbatis esetében a birtoklás tényét rögzíti az, hogy a névben megjelenik az apát 'kolostor élén álló szerzetes föpap' (TESz. apát a.) méltóságnév (vö. То́тн 2001: 148). ${ }^{20}$ A méltóságnév a korban személynévként is ismert volt (vö. pl. 1221, 1240: Apat, 1246/1293: Apath; ÁSznt. 71), de KázMÉr MikLós szerint a helynevekben inkább a méltóságnév elöfordulását kell gyanítanunk, az apát főnév ugyanis csak kivételes esetekben vált személynévvé (1970: 110). A Tihanyi alapítólevélben és a Garamszentbenedeki oklevélben sem szerepel olyan név, amely az apát fönévből alakult volna, de a későbbiekben a nevek megváltoztatása révén (vö. TóTH 2008: 28, 30) ez a névadási szokás mindkét apátság birtokainak esetében tetten érhető: Disznó > Apáti; Knyezsic $>$ Apáti (HofFMAnN 2010a: 98, SzöKe 2013).

A Pécsváradi alapítólevél névformájának keletkezését illetően - további adatok hiányában - többféle lehetőség is felmerülhet. Ezek közül az tünik a legkevésbé valószínünek, hogy ez a név már az alapítás óta szerepelhetett az oklevélben. Ez azt feltételezné ugyanis, hogy az alapításkor elnevezett terület nevében azonnal jelezték az apátsági birtoklást, vagy a már meglévő nevet az alapítólevél kiállításakor a megváltozott körülmények motiválta új névre cserélték. Ez már csak azért is valószínütlennek tünik, mert egy kaszálóról és nem egy birtokról van szó. A névforma sokkal inkább az oklevél bizonytalan státuszával magyarázható: a helynév a hamisítás vagy az átírások során kerülhetett bele a szövegbe.

4.2. A birtokadományozó részben szereplő másik latin név a Sirmia településnév. Ez a Bodrog megyei Ilsán település határleírásában szerepel: „quinta Ylsan nominatur, que ab oriente terminatur Kynesa, ab austro Sirmia, ab occidente Totis, a septentrione Fornogis" (DHA. 1: 73). Szerémvár és Szerémség jelölésére az ókori latin Sirmium nevet használták, és a Pécsváradi alapítólevél azt mutatja, hogy az elszármazott lakosság Bodrog vármegyei

${ }^{20}$ Köszönöm Szöcs TiBornak, hogy felhívta a figyelmemet Dávid dux eredeti oklevelének (1090 k.) egy részletére, amely megmutatja, hogy már a 11. század óta úgy tekintettek egy egyháznak tett adományra, hogy az az intézmény tulajdona, amellyel az apát (nem egyszer személyesen is) él: „In Danubio [...] quod [cape]retur in ansis, Sancti Aniani abbas haberet, et in elevatione ansarum ipse ad suscipiendos pisces aforet vel suus minister” (DHA. 1: 265). Magyarul: „A Dunán [...] amit a varsákban fognak, Szent Ányos apátjáé legyen, és a varsák kiemelésekor ő maga legyen jelen a halak átvételénél, vagy a szolgája" (DrESKA 1997: 118). 
településének megnevezéseként is használatos volt ez a név (Gy. 1: 720, FNESz. Szerémség a., Póczos 2001: 113, KMHsz. 1: 262, HoffMAnN-RÁcz-Tóth 2018: 54).

4.3. A településnevek egy jelentős részének latinos formáit a hangalak és a morfológiai szerkezet módosításával hozták létre a hazai oklevelezésben. Az érseki székhely és a Fejér megyei Kalocsa nevének (Strigoniensis archiepiscopi, Strigoniensi archiepiscopo, Colocensis archiepiscopi; DHA. 1: 76, 80) az alapítólevélben ilyen formában való megjelenése tökéletesen illeszkedik ehhez a szokáshoz (Gy. 2: 237-245, 427-430; HoffmANN 2004: 24-25; SzÖKE 2008: 271).

4.4. A Pécsváradi alapítólevél az apátság helyét egy hegyhez képest jelöli ki. Ennek a hegynek a neve latinul szerepel az oklevélben: ,monasterium Sancte Dei Genitricis Marie et Sancti Benedicti ad radicem Montis Ferrei diligenter construximus" (DHA. 1: 72). Az apátság a ma Zengö-nek nevezett hegy lábánál létesült, de a Mecsek legmagasabb pontjának a korabeli magyar névmegfelelöje nem maradt fenn a forrásokban. Pécsvárad mellett fekszik azonban a Vasas nevü település (Gy. 1: 403), az ugyancsak szomszédos Hosszúhetény határából pedig egy Vasas-tető határnevet ismerünk (BMFN. 1: 588). Ezek alapján az alapítólevél latin alakját talán Vas(as)-hegy-nek rekonstruálhatjuk (PESTY 1888: 408, HoFFMANN-RÁcz-Tóth 2018). ${ }^{21}$

A 11. század után a Mons Ferreus önmagában nem fordul elő az apátság megnevezéseként. A leghitelesebbnek tünő forrás ebből az évszázadból István király 11. század végén keletkezett nagyobbik legendája: „Aescricus abbas cum suis honorifice susceptus, ad radicem Montis Ferrei cenobium sub titulo sancti patris Benedicti construxit" (SRH. 2: 382-383). A hamisítás korában (a 13. század első felében) már a Várad névvel nevezték meg a települést, az apátságot pedig gyakran a két név együtt jelölte: 1224/399: „,mon-i Subradice Montis Ferrei Waradiensis" (Gy. 1: 363). A településnévnek a maival megegyező alakja - igaz, ekkor még a Várad-dal váltakozva - a 14. századtól adatolható, és ekkortól sokszor már az apátok, illetve az apátság is pécsváradiként vannak megnevezve: 1323/1403/Pp.: „conventus monasterii de Pechwaradino” és „abbas de Pechwaradino”, Vat. I/4: 573 (mindehhez vö. KarÁcsonyi 1891: 92, Gy. 1: 362-364, KöFalvi 2000, Gállos 2001: 107-108). Ezek az adatok a Szent István alapítólevelét átíró oklevélből valók, ami azt mutatja, hogy az átírt alapítólevélben az átíró oklevél újabb formái (Várad, Pécsvárad) ellenére maradt meg a régebbi (vélhetően 11. századi) változat (az átírt és az átíró oklevelek különböző névformáihoz l. KenYHercz 2016). A Mons Ferreus nevet ezek alapján az alapítólevél legkorábbi kronológiai rétegéhez sorolhatnánk (vö. HECKENAST 1966: 157, GÁLlos 2001: 107), a névalak azonban egy évjelzés nélküli oklevélben is felbukkan (Ferreo Monte, PRT. 1: 698). Az oklevélben szereplő Ubald szenttamási prépost alapján ez az irat a 13. század elejére (1230k.) datálható (PRT. 1: 698, 700; vö. Gy. 1: 363, KöFALVI 2000: 289). Mindebből az következik, hogy a hamis oklevél keletkezésekor, a 13. század elején (valószínüleg nem nagy számban) még használták a Pécsváradi alapítólevélben lévő alakot (vö. KöFALvi 2000: 288), az alapítólevélbeli latin név kronológiai minősítése tehát inkább bizonytalannak tünik.

${ }^{21}$ A Zselic névvel való kapcsolatára ezúttal nem térek ki (ehhez 1. Gy. 1: 247, HecKenAST 1966: 156-157, Gállos 1975: 22, Kiss L. 1988: 134, FNESz. 1: 815, Pesti 2014: 15-24). 
5. A latinul szereplő neveknek az alapítólevél összes megjelöléséhez mérten csekély száma és a latin helyett vulgáris nyelvü elemeknek a használata (a Duna név, a fanevek és a földrajzi köznevek) kapcsán felvetettem, hogy ezek talán egy 11. századi (Szent Istvánkori) oklevél lenyomataként értelmezhetők. A jelenlegi elemzés újabb adalékokat nyújt tehát ahhoz (vö. SzÖKE 2019a, 2019b, 2020), hogy a bizonytalan kronológiai státuszú Pécsváradi oklevélben a 11. századi oklevél jellegzetességei sokkal nagyobb mértékben őrződhettek meg az oklevél fennmaradt 15. századi változatában, mint azt korábban gondolták.

Ez az oklevél amellett, hogy a 11. századi nyelvi adatainkat gazdagítja, az oklevelezési gyakorlat kezdeteinek a jobb megismeréséhez is jelentős mértékben hozzájárul. A Pécsváradi oklevélből ehhez a kezdeti időszakhoz kötött elemek kronológiai értékélését Szent István király többi oklevelének ismeretében hasznos lehet újra megvizsgálni. Ebbe a vizsgálatba a valóban István korában keletkezett, de későbbi változatban fennmaradt okleveleken túl a hamis, de vélhetően 11. századi előzményre visszavezethető oklevelek is bekapcsolhatók. Ezek azok az oklevelek ugyanis, amelyek alapján a magyarországi oklevél-kiállítás kezdeteire jellemző eljárásokat feltárhatjuk. Fontos lenne tisztázni, hogy valóban az oklevélkiállítási normák korabeli kialakulatlanságáról beszélhetünk-e, vagy éppenséggel a későbbiektől eltérő normákhoz igazodtak az oklevelek kiállításában részt vevő személyek. Ez a vizsgálat azonban nemcsak a 11. század eleji eredeti oklevelek hiánya miatt, hanem azért is nehézségekbe ütközhet, mert ösztönös megoldásokkal még a normák megszilárdulásának a korában is bőséggel számolhatunk (BENKÖ 1996: 237, HOFFMANN-RÁCZ-TóTH 2018: 95-96).

\section{Hivatkozott irodalom}

AO. = Anjoukori okmánytár / Codex diplomaticus Hungaricus Andegavensis 1-7. Magyar történelmi emlékek. 1. oszt., Okmánytárak / Monumenta Hungariae historica. Diplomataria. [1-6.] Szerk. Nagy Imre. MTA, Budapest, 1878-1891. [7.] Szerk. TasnÁdi Nagy Gyula. MTA, Budapest, 1920.

ÁSznt. = FehérTói Katalin, Árpád-kori személynévtár 1000-1301. Akadémiai Kiadó, Budapest, 2004. ÁÚO. = Árpádkori új okmánytár / Codex diplomaticus Arpadianus continuatus 1-12. Közzé teszi Wenzel Gusztáv. [1-9.] Pest, [10-12.] Budapest, 1860-1874.

BÁBA BARBARA 2008. A fanevet tartalmazó helynevek morfológiai szempontú vizsgálata. In: BölcsKei Andrea - N. Császi Ildikó szerk., Név és valóság. A VI. Magyar Névtudományi Konferencia elöadásai (Balatonszárszó, 2007. június 22-24.). A Károli Gáspár Református Egyetem Magyar Nyelvtudományi Tanszékének Kiadványai 1. Károli Gáspár Református Egyetem Magyar Nyelvtudományi Tanszéke, Budapest. 53-59.

BÁBA BARBARA 2012. Fanevek helynévformáns szerepe a korai ómagyar korban. Helynévtörténeti Tanulmányok 7: 69-75.

BÁBa Barbara 2016. Földrajzi köznevek térben és időben. A Magyar Névarchívum Kiadványai 39. Debreceni Egyetemi Kiadó, Debrecen.

Balázs János 1980. Magyar deákság. Anyanyelvünk és az európai nyelvi modell. Magvető Kiadó, Budapest.

Balázs JÁnos 1989. A latin a Duna-tájon. In: BaLÁzs JÁnos szerk., Nyelvünk a Duna-tájon. Tankönykiadó, Budapest. 95-140. 
Bartal Antal 1901. A magyarországi latinság szótára / Glossarium mediae et infimae Latinitatis regni Hungariae. Franklin Társulat, Budapest.

BENKő LoRÁnd 1995. Mi a helyzet Zalán vezér neve és személye körül? Magyar Nyelv 91: 402-411.

BENKÖ LoRÁND 1996. Anonymus élő nyelvi forrásai. In: KovÁcs LÁszLÓ - VeszPrémy László szerk., A honfoglaláskor irott forrásai. Balassi Kiadó, Budapest. 221-247.

BENKÖ LoRÁnd 1998. Név és történelem. Tanulmányok az Árpád-korról. Akadémiai Kiadó, Budapest.

BenKö Loránd 2003. Beszélnek a múlt nevei. Tanulmányok az Árpád-kori tulajdonnevekröl. Akadémiai Kiadó, Budapest.

Bényei Ágnes - Pethö Gergely 1998. Az Árpád-kori Győr vármegye településneveinek nyelvészeti elemzése. A Magyar Névarchívum Kiadványai 2. Debreceni Egyetem Magyar Nyelvtudományi Tanszéke, Debrecen.

BMFN. = Baranya megye földrajzi nevei 1-2. Szerk. Pesti János. Baranya Megyei Levéltár, Pécs, 1982.

CsŐRE PÁL 1972. Az erdei fák szerepe a régi határleírásokban és ennek erdőtörténeti jelentősége. Erdészettörténeti Közlemények 5-7: 17-26.

DF. = Diplomatikai Fényképgyüjtemény. http://mol.arcanum.hu

DHA. = Diplomata Hungariae antiquissima. Accedunt epistolae et acta ad historiam Hungariae pertinentia. 1. Ab anno 1000 usque ad annum 1196. Edendo operi praefuit GeOrgIUS GYÖRfFY. Akadémiai Kiadó, Budapest, 1992.

Dreska GÁBOR 1997. Dávid herceg nagybátyjának, I. Lászlónak, Magyarország királyának engedélyével földeket, halászhelyeket és szolgákat adományoz Szent Ányos tihanyi monostorának. In: GYÖRFFY GYÖRGY föszerk., Árpád-kori oklevelek. 1001-1196. Balassi Kiadó, Budapest.

ECKHART FERENC 1910. A pápai és császári kanczelláriai gyakorlat hatása Árpádkori királyi okleveleink szövegezésében. Századok 44: 713-724.

Érszegr Géza 2000. Szent István király Pécsváradi alapitólevele. Galenus Lapkiadó Kft., Budapest.

EWUng. = Etymologisches Wörterbuch des Ungarischen 1-2. Hrsg. BENKÖ, LoRÁND. Akadémiai Kiadó, Budapest, 1993-1995. + Register. Akadémiai Kiadó, Budapest, 1997.

FejÉrPataky László 1885. A királyi kanczellária az Árpádok korában. Magyar Tudományos Akadémia, Budapest.

FinÁly HeNRIK 1884. A latin nyelv szótára: a kútfökböl a legjobb és legújabb szótárirodalomra támaszkodva. Franklin Társulat, Budapest.

FKnT. = BÁBA BARBARA - Nemes Magdolna, Magyar földrajzi köznevek tára. A Magyar Névarchívum Kiadványai 32. Debreceni Egyetemi Kiadó, Debrecen, 2014.

FNESz. = KIss LAJos, Földrajzi nevek etimológiai szótára 1-2. 4., bővített és javított kiadás. Akadémiai Kiadó, Budapest, 1988.

Gállos Ferenc 1975. Tanulmányok Pécsvárad középkori történetéhez. S. a. r. GÁllos Orsolya. Dunántúli Dolgozatok 8. Janus Pannonius Múzeum, Pécs.

Gállos Ferenc - GÁllos Orsolya 2001. Pécsvárad bencés apátsága és települése a középkorban. In: FüzesI MikLós szerk., Pécsvárad. Pécsvárad város önkormányzata, Pécsvárad. 103-197.

Gouth Kálmán 1936. Az okleveles bizonyitás kifejlödése Magyarországon. Királyi Magyar Egyetemi Nyomda, Budapest.

Gy. = Györffy György, Az Árpád-kori Magyarország történeti földrajza 1-4. Akadémiai Kiadó, Budapest, 1963-1998.

GYÖRFFY GYÖRGY 1969. A magyar egyházszervezés kezdeteiről újabb forráskritikai vizsgálatok alapján. MTA Filozófiai és Történettudományok Osztályának Közleményei 18: 199-225. 
GYÖRfFY GYÖRGY 1970. A helynevek és a történettudomány. In: KÁZMÉr MiKLós - VÉGH JózSEF szerk., Névtudományi elöadások. II. névtudományi konferencia. Budapest, 1969. Nyelvtudományi Értekezések 70. Akadémiai Kiadó, Budapest. 196-200.

GYÖRFFY GYÖRGY 1977. István király és müve. Gondolat Kiadó, Budapest.

GyÖRfFY GyÖRGY 1997. Árpád-kori oklevelek. 1001-1196. Balassi Kiadó, Budapest.

H. = Hazai okmánytár / Codex diplomaticus patrius 1-8. Kiadják: [1-5.] NAGY IMre - PAUR IVÁN RÁth Károly - Véghely Dezsö. Sauervein, Győr, 1865-1873. [6-8.] Ipolyi Arnold - Nagy ImRe VÉGHely Dezsö. Franklin, Budapest, 1876-1891.

HA. = HOFFMANN ISTVÁN - RÁCZ ANITA - TÓTH VALÉRIA, Helynévtörténeti adatok a korai ómagyar korból 1-4. A Magyar Névarchívum Kiadványai 1, 3, 25, 43. KLTE Magyar Nyelvtudományi Tanszék / Debreceni Egyetemi Kiadó, Debrecen, 1997-2017.

Heckenast Gusztáv 1966. A kora-Árpádkori magyar vaskohászat. Történelmi Szemle 9: 135-171.

Hoffmann István 1993. Helynevek nyelvi elemzése. A Debreceni Kossuth Lajos Tudományegyetem Magyar Nyelvtudományi Intézetének Kiadványai 61. Kossuth Lajos Tudományegyetem Magyar Nyelvtudományi Intézete, Debrecen.

HoFfMANN István 2004. Az oklevelek helynévi szórványainak nyelvi hátteréröl. Helynévtörténeti Tanulmányok 1: 9-61.

HoFFMANN IsTVÁN 2006. Szöveg és szórvány kapcsolata a Tihanyi apátság alapítólevelében. In: GALGÓCZI LÁszló - VASS LÁszLó szerk., A mondat: kaland. Hetven tanulmány Békési Imre 70. születésnapjára. Juhász Gyula Főiskola, Szeged. 142-147.

HoFfmann István 2007. A Tihanyi alapitólevél mint helynévtörténeti forrás. (A régi magyar helynevek vizsgálatának alapkérdései). Akadémiai doktori értekezés, MTA, Budapest. http://real-d. mtak.hu/37 (2020. 10. 10.)

HoFFMAnN István 2010a. A Tihanyi alapitólevél mint helynévtörténeti forrás. A Magyar Névarchívum Kiadványai 16. Debreceni Egyetemi Kiadó, Debrecen.

HofFMANN IsTvÁN 2010b. Dél-dunántúli helynevek a pécsi püspökség alapítólevelében. In: NÉMETH Miklós - Sinkovics Balázs szerk., Tanulmányok Szabó József 70. születésnapjára. Szegedi Tudományegyetem Magyar Nyelvészeti Tanszék, Szeged. 77-82.

HoFFMANN IstVÁN - RÁcz ANITA - Tóth VALÉRIA 2018. Régi magyar helynévadás. A korai ómagyar kor helynevei mint a magyar nyelvtörténet forrásai. Gondolat Kiadó, Budapest.

KARÁCSONYI JÁnos 1891. Szent-István király oklevelei és a Szilveszter-bulla. Magyar Tudományos Akadémia, Budapest.

KárOkl. = A nagy-károlyi gróf Károlyi család oklevéltára / Codex diplomaticus comitum Károlyi de Nagy-Károly 1-5. Sajtó alá rendezi Géresi Kálmán. Budapest, 1882-1897.

KÁzmér MikLós 1970. A »falu« a magyar helynevekben. XIII-XIX. század. Nyelvészeti tanulmányok 13. Akadémiai Kiadó, Budapest.

KENYHERCZ RÓBERT 2016. A középkori oklevelek átírási gyakorlatának nyelvtörténeti vonatkozásai. Helynévtörténeti Tanulmányok 12: 7-44.

Kisd KlÁra 1999. Szent István király nagyobbik legendája. In: KRISTó GyUla szerk., Az államalapitás korának irott forrásai. Szegedi Középkortörténeti Könyvtár 15. Szegedi Középkorász Mühely, Szeged. 269-298.

Kiss Gergely 2001. Jogbiztosítás a pécsváradi bencés monostorban a 12-13. században. Adalékok a magyarországi exemptio történetéhez. In: Font MártA - VArgha Dezső szerk., Tanulmányok Petrovich Ede tiszteletére. A Petrovich Ede Emlékkonferencia (Pécs, 1998. szeptember 21). Pécs Története Alapítvány, Pécs. 87-99. 
KISS LAJOS 1988. Magyarország földrajzi és társadalmi arculata az Árpád-korban. Magyar Nyelv 84: $129-155$.

KMHsz. = Korai magyar helynévszótár 1000-1350. 1-. Szerk. Hoffmann IstvÁN. A Magyar Névarchívum Kiadványai. 10. Debreceni Egyetem Magyar Nyelvtudományi Tanszék, Debrecen, 2005-.

KovÁcs Éva 2015. A Tihanyi összeírás mint helynévtörténeti forrás. A Magyar Névarchívum Kiadványai 34. Debreceni Egyetemi Kiadó, Debrecen.

Kovács Éva 2018. A Százdi alapitólevél mint helynévtörténeti forrás. A Magyar Névarchívum Kiadványai 48. Debreceni Egyetemi Kiadó, Debrecen.

KÖFALVI TAMÁs 2000. Pécsvárad nevéröl, különös tekintettel a konvent hiteleshelyi gyakorlatára. In: Piti Ferenc - Szabados GyÖrgy szerk., ,, Magyaroknak eleiröl”. Ünnepi tanulmányok a hatvan esztendős Makk Ferenc tiszteletére. Szegedi Középkorász Mühely, Szeged. 287-306.

Kristó Gyula 1999. A tizenegyedik század története. Pannonica Kiadó, Budapest.

Kristó GyUla 2000. Szent István pécsváradi okleveléről. In: Piti Ferenc - Szabados GyöRgy szerk., „Magyaroknak eleiröl”. Ünnepi tanulmányok a hatvan esztendös Makk Ferenc tiszteletére. Szegedi Középkorász Mühely, Szeged. 307-321.

OklSz. = Magyar oklevél-szótár. Régi oklevelekben és egyéb iratokban elöforduló magyar szók gyüjteménye. Pótlék a Magyar nyelvtörténeti szótárhoz / Lexicon vocabulorum Hungaricorum. In diplomatibus aliisque scriptis quae reperiri possunt vetusto. Gyüjt. Szamota István. Szótárrá szerk. Zolnai Gyula. Hornyánszky, Budapest, 1902-1906.

ÓmOlv. = Ó-magyar olvasókönyv. Szerk. JAKUBovich EmIL - PAis Dezső. Danubia, Pécs, 1929.

Pesti János 2014. Hosszúhetény nyelvi kincseiröl. Névtani és dialektológiai tanulmányok. Hosszúhetényi Honismereti Füzetek 7. Nemes János Mủvelődési Központ, Hosszúhetény.

Pesty Frigyes 1888. Magyarország helynevei történeti, földrajzi és nyelvészeti tekintetben 1. MTA Történelmi Bizottsága, Budapest.

Póczos Rita 2011. Az Árpád-kori Borsod és Bodrog vármegye településneveinek nyelvészeti elemzése. A Magyar Névarchívum Kiadványai 5. Debreceni Egyetem Magyar Nyelvtudományi Tanszéke, Debrecen.

Póczos Rita 2015. A Pécsi püspökség alapítólevelének helynévi szórványai: Lupa, Kapos. Helynévtörténeti Tanulmányok 11: 69-83.

Solymosi LÁszló 2006. Írásbeliség és társadalom az Árpád-korban. Argumentum Kiadó, Budapest.

SRH. = Scriptores rerum Hungaricarum tempore ducum regumque stirpis Arpadiane gestarum 1-2. Edendo operi praefuit Emericus Szentpétery. Academie Litter. Typ. Universitatis, Budapest, 1937-1938.

SZENTGYÖRGYi Rudolf 2008. A Tihanyi alapítólevél kangrez szórványáról. Helynévtörténeti Tanulmányok 3: 29-52.

SzENTGYÖRGYI RUDOLF 2009. Terminológiai széljegyzet a Tihanyi alapítólevél kétnyelvű helymeghatározásaihoz. Magyar Nyelv 105: 62-68.

SzENTGYÖRGYI RUDOLF 2010a. Helynevek beillesztése korai latin nyelvü okleveleink szövegébe. Helynévtörténeti Tanulmányok 5: 33-45.

SZENTGYÖRGYI RUDOLF 2010b. A nyelvi kölcsönhatás nyomai korai ómagyar okleveleinkben. In: É. Kiss Katalin - Hegedüs Attila szerk., Nyelvelmélet és kontaktológia. PPKE BTK Elméleti Nyelvészeti Tanszék - Magyar Nyelvészeti Tanszék, Piliscsaba. 71-86.

SzentGyöRgYi Rudolf 2010c. A Tihanyi alapítólevél szövege. In: HofFmann István, A Tihanyi alapitólevél mint helynévtörténeti forrás. A Magyar Névarchívum Kiadványai 16. Debreceni Egyetemi Kiadó, Debrecen. 21-41. 
SZENTGYÖRGYi Rudolf 2014. A Tihanyi apátság alapitólevele 1. Az alapitólevél szövege, diplomatikai és nyelvi leírása. ELTE Eötvös Kiadó, Budapest.

SzENTPÉTERY IMRE 1918. Szent István király pécsváradi és pécsi alapitólevele. Magyar Tudományos Akadémia, Budapest.

Szentpétery ImRe 1930. Magyar oklevéltan. Magyar Történelmi Társulat, Budapest.

SzENTPÉTERY ImRE 1938. Szent István király oklevelei. In: SERÉDI JuSZTINIÁN szerk., Emlékkönyv Szent István király halálának kilencszázadik évfordulóján 1-3. Magyar Tudományos Akadémia, Budapest. 2: 133-202.

Szerémi [Odescalchi ARThur] 1883. Az erdei fák régi magyar nevei. Második közlemény. Erdészeti Lapok 22: 133-144.

SzovÁK Kornél 2001. Monachorum pater ac dux. A bencés szerzetesség korai századai Magyarországon. In: TAKÁCs ImRE szerk., Paradisum plantavit. Bencés monostorok a középkori Magyarországon. Bencés Főapátság, Pannonhalma. 35-47.

SzÖKe Melinda 2008. Régi helyneveink latinizálása. In: BölcskeI ANDREA - N. CsÁszi Ildikó szerk., Név és valóság. A VI. Magyar Névtudományi Konferencia előadásai (Balatonszárszó, 2007. június 22-24.). A Károli Gáspár Református Egyetem Magyar Nyelvtudományi Tanszékének Kiadványai 1. Károli Gáspár Református Egyetem Magyar Nyelvtudományi Tanszéke, Budapest. 267-271.

SzÖKE MELINDA 2013. Az apát lexéma megjelenése a garamszentbenedeki apátság birtokainak nevében. Névtani Értesitö 35: 109-122.

SzŐKE Melinda 2015. A garamszentbenedeki apátság alapitólevelének nyelvtörténeti vizsgálata. A Magyar Névarchívum Kiadványai 33. Debreceni Egyetemi Kiadó, Debrecen.

SzÖKE Melinda 2019a. Szent István Pécsváradi oklevelének Sorlogys helynevéröl és ami körülötte lehetett. Névtani Értesitö 41: 91-106. https://doi.org/10.29178/nevtert.2019.5

SzÖKe Melinda 2019b. A Pécsváradi oklevél Scedluc helynevéröl. Helynévtörténeti Tanulmányok 15: 107-120. https://doi.org/10.35528/helynevtort/15/05

SzÖKE Melinda 2020. A Pécsváradi oklevél helyneveinek szövegkörnyezete. Magyar Nyelvjárások 58: 109-120. https://doi.org/10.30790/mnyj/2020/05

TESz. = A magyar nyelv történeti-etimológiai szótára 1-3. Föszerk. BENKö LoRÁND. Akadémiai Kiadó, Budapest, 1967-1976. + Mutató. Akadémiai Kiadó, Budapest, 1984.

Thoroczkay Gábor 2009. Szent István okleveleiről. Századok 143: 1385-1412.

TóTH VALÉRIA 2001. Névrendszertani vizsgálatok a korai ómagyar korban (Abaúj és Bars vármegye). A Magyar Névarchívum Kiadványai 6. Debreceni Egyetem Magyar Nyelvtudományi Tanszéke, Debrecen.

TÓTH VALéria 2008. Településnevek változástipológiája. A Magyar Névarchívum Kiadványai 14. Debreceni Egyetem Magyar Nyelvtudományi Tanszéke, Debrecen.

Vat. = Monumenta Vaticana historiam regni Hungariae illustranta. Series I. Tom. 1-6. Szent István Társulat, Budapest, 1885-1891.

Zelliger Erzsébet 2005. A Tihanyi Alapitólevél. Bencés Kiadó, Pannonhalma.

SZÖKE MELINDA

ORCID: https://orcid.org/0000-0003-2726-4973

Debreceni Egyetem Bölcsészettudományi Kar 


\section{Melinda SzőKe, The Latinization and its absence in the foundation charter of Pécsvárad Abbey}

The founding charter of Pécsvárad Abbey $(+1015 /+1158$ [about 1220]/1323/1403/PR.) is a document that has only survived in a $15^{\text {th }}$-century copy of a $13^{\text {th }}$-century forgery. Thus, an analysis of toponym history and linguistic history must deal with several chronological planes when studying the document. The first section of this study examines Hungarian words (Duna 'Danube'; the names of trees: e.g. tulfa 'oak', scylfa 'elm'; geographic common nouns: e.g. aruc 'ditch', nogwt 'main road') that are used only in Latin in other documents or are characterised by mixed usages of Latin and Hungarian terms. These indicate a lack of Latinisation. The second section details the characteristics of five Latin name forms used in the document (Scena abbatis, Sirmia, Strigoniensis, Colocensis, Montis Ferrei), emphasising their chronological order. The small number of Latin names among all designations in the charter and the use of vulgar elements instead of Latin is presented as an imprint of $11^{\text {th }}$-century charter writing (from the time of Saint Stephen). Thus, the charter can provide significant insight into the beginnings of charter writing in Hungary. 